\title{
Online Course Design and Development Among College and University Instructors: An Analysis Using Grounded Theory
}

\author{
Sally J. Baldwin, Yu-Hui Ching, and Norm Friesen \\ Boise State University
}

\begin{abstract}
In this study, a grounded theory approach was used to investigate the process college and university instructors undergo to design and develop online courses. Fourteen instructors who created online courses for four-year colleges and universities were interviewed about their experience designing and developing online courses. Results showed that participants begin the process with objectives and/or existing course outlines, typically taken from online and face-to-face courses. Next, the instructors structure the course and chunk content. The instructors interviewed rarely use formal instructional design models, but their design tasks show a striking similarity to those formalized in the ADDIE model. Student feedback (evaluation) motivated the instructors in their development efforts after initial course delivery. The study discusses practical implications and suggests opportunities for future research.
\end{abstract}

Keywords: instructional design, instructional strategy, learning management system, online learning

Baldwin, S.J., Ching, Y.-H., \& Friesen, N. (2018). Online course design and development among college and university instructors: An analysis using grounded theory. Online Learning, 22(2), 157-171. doi:10.24059/olj.v22i2.1212

\section{Online Course Design and Development Among College and University Instructors: An Analysis Using Grounded Theory}

Instructional design focuses on improving the process of instruction by "prescribing optimal methods of instruction to bring about desired changes in student knowledge and skills" (Reigeluth, 2013, p. 4). The instructional design of a course creates learning environments and experiences that favorably impact conditions for learning (Merrill, Drake, Lacy, \& Pratt, 1996). In online courses, there is a strong link between the tasks of designing and teaching. A national survey of 10,700 college and university faculty instructors found that "over 80 percent of faculty involved in online teaching and/or development are involved in both the development and the teaching aspects" for a given course (Seaman, 2009, p. 21). However, research shows that creating an online 
course involves a different set of skills than delivering content in a traditional course setting (Miller, 2007).

Research also confirms the importance of instructional design for online instructors. Baran, Correia, and Thompson (2011) performed an extensive literature review and used a constant comparison analysis to determine online instructors' key responsibilities. The researchers found that aspects of instructional design (i.e., planning, organizing, and structuring the course) were often considered the most important tasks for online instructors. Bawane and Spector (2009) conducted a study to help identify instructor competencies for new online teaching programs. The ability to design instructional strategies and develop appropriate learning resources, implement instructional strategies, and facilitate participation and sustain motivation among students were found to be the most important skills for online instructors (Bawane \& Spector, 2009). The "ability to design courses well is usually the most limiting factor" (Fink, 2003, p. 34) in teaching effectively online. In a poorly designed course, students become disengaged, and learning suffers (Koszalka $\&$ Ganesan, 2004). Student satisfaction and perceived learning have been linked to clarity of design in online education (Swan, 2001).

Educational researchers have focused on the attitudes of instructors toward online instruction, typically using surveys (Allen \& Seaman, 2016; Jaschik \& Lederman, 2014; Seaman, 2009; Worthen, 2013), and as a result there is limited insight into individual experiences and knowhow involved in online course design. While survey data is valuable, no existing survey studies address the online course design aspect. A review of the literature failed to provide information on how instructors design online courses. This information is important in order to provide instructors with a voice to explain their process of online course design.

The purpose of this study is to determine how instructors design online courses at public four-year colleges and universities. The intent is to help direct the conversation about instructional design to one that is grounded in practice. This study utilizes interviews with instructors who design and teach online courses and employs a grounded theory approach to add to the scant knowledge on this common design condition. This research aims to answer the following question: How do instructors design online courses at public four-year colleges and universities, and how can this practice be theorized?

\section{Instructional Design Models}

\section{Review of Related Literature}

This study uses grounded theory to generate a theory that is grounded in instructors' reports of their online course design experiences. In the context of instructional design, research suggests explicit models and processes (i.e., steps). ADDIE, an acronym naming the processes of analysis, design, development, implementation, and evaluation (Huguet, 2008), is among the most important of these design process models (Smith \& Ragan, 2004). During the analysis phase, the instructor establishes the direction of the course, reviews the learning environment, and identifies learners' existing knowledge and skills. In the design and development phase, the instructor takes systematic and specific actions to write learning objectives, create content, plan lessons, choose assessment instruments, and select media based on the results of the earlier analyses. The instructor conducts instruction during the implementation phase, and in the final phase, evaluation, the instructor evaluates and revises the course or lesson (Clark, 2015). According to instructional design models, instructors must understand learners' characteristics and needs before they 
determine how to deliver content to meet these needs, while providing formative and summative evaluations to confirm needs are met (Dick, Carey, \& Carey, 2014; Morrison, Ross, Kalman, \& Kemp, 2010; Smith \& Ragan, 2004).

ADDIE is a generalized instructional design process model (Ippoliti \& Gammons, 2016), but there are other closely related instructional design models. These models use a formalized systems view of the process, as well as its components and outcomes (e.g., the Dick and Carey systems approach), in which each component (i.e., instructor, learners, materials, and learning environment) is deemed crucial to success. Other instructional design models include, but are certainly not limited to, Keller's ARCS model of motivational design (Keller, 1987), Wiggins and McTighe's backward design model (Wiggins \& McTighe, 1998), and the Kemp design model (Morrison et al., 2010). Instructional design, as formalized in these and other models, is defined as "a system of procedures for developing education and training curricula in a consistent and reliable fashion" (Branch \& Merrill, 2012, p. 8). It involves a "systematic and reflective process of translating principles ... into plans for instructional materials, activities, information resources, and evaluation" (Smith \& Ragan, 2004, p. 4). As depicted in these models, instructional design is "widely considered to be equivalent to process" (Boling \& Smith, 2012, p. 358), and students of instructional design are often encouraged to use these models to guide their instructional design endeavors.

\section{Instructional Design in Practice}

While the theoretical approach to instructional design is popular in academia, this popularity does not extend to practice (Zierer \& Seel, 2012). Instructional designers, professionals whose primary responsibility is to design courses, tend to use instructional design models broadly. Instructional designers are aware of process-based instructional design models but do not follow these models in a rigid fashion or spend a great deal of time using them (Kenny, Zhang, Schwier, \& Campbell, 2005). York and Ertmer (2011) found that instructional designers often use general guidelines and modified models to design courses, based on the results of a series of surveys sent to 50 experienced instructional designers. In another study, Ertmer et al. (2008) provided illstructured instructional design problems to seven instructional designers and asked the practitioners to use a think-aloud procedure to investigate their problem-solving processes. The researchers found that instructional designers use their previous knowledge and personal experience to interpret the problem and then use a mental model of the instructional design process to solve the problem. The researchers also discovered that it was important for the instructional designers to be able to draw on past designing experiences. Other research supports these findings, suggesting that instructional designers adapt instructional design models (Christensen \& Osguthorpe, 2004; Kirschner, Carr, van Merriënboer, \& Sloep, 2002; Silber, 2007). Wedman and Tessmer's (1993) survey of instructional design activities practiced by 73 instructional designers indicated that the practitioners alter activities and the sequence of activities included in instructional design models. The practitioners cited lack of time, decisions already made, and activities considered unnecessary as reasons for omitting design activities.

\section{Instructors Designing Online Courses}

Institutions often recruit instructors to design online courses (Baran et al., 2011; Seaman, 2009). Instructors are content experts, familiar with the learners, and already a part of the institution. However, there is a paucity of research about how instructors design online courses. Researchers have examined the design and implementation of online learning activities, such as 
discussion forums (Clark, 2015; McDonald, 2009), wikis (West \& West, 2009), and student assessment (Anderson, 2004). Researchers have also investigated instructors' assessment of the usefulness of various components in specific courses (Kihato \& Bednar, 2004). Faculty from public and private institutions have been surveyed about their perception of online learning (Straumsheim, Jaschik, \& Lederman, 2015). The Coalition of Contingent Academic Labor surveyed faculty from 107 institutions to understand online instructors' professional concerns (Worthen, 2013). These concerns focused on control of work, job security, and ownership of copyrights, not the process of course design. Barberà, Layne, and Gunawardena (2014) found prior experience and institutional systems played a part in the quality of online course design in three academic disciplines, but the study did not provide detailed information to explain the role of instructors involved in course design. Alvarez, Guasch, and Espasa (2009) identified the course design process as consisting of "[1] defining the procedures of instructional design; [2] considering the resources and the assessment in a virtual context; [3] presenting content/questions; [4] translation of traditional content in online contents with interactive activities for students; [5] creation of online interactive content" (p. 332). However, the instructors' perspective on these tasks was not included. Kang (2000) performed a case study to investigate the process of moving traditional courses to an online format at Northern Illinois University. Kang identified instructional strategies based on interviews with instructors, instructional designers, and administrators. Kang limited this study to one university, and it included instructional designers who assisted with the process.

Existing instructional design models mostly prescribe the design process, components, and outcomes (Becker, 2007), but current literature offers little insight about how instructors actually design online courses. Grounded theory provides an opportunity to gain a different understanding of course design by speaking directly with instructors about what they are actually doing, rather than relying on literature written about how courses should be designed. In the next section, more information will be provided to describe the method used in this study.

\section{Methods}

This study used grounded theory to investigate how instructors design online courses. Grounded theory involves the "discovery of theory from data systematically obtained from social research" (Glaser \& Strauss, 1967, p. 2). The goal of grounded theory is to generate a theory "that accounts for a pattern of behavior which is relevant ... to those involved" (Glaser, 1978, p. 93). Glaser and Strauss (1967) note that the theory produced is not a perfect description of the whole field. Rather, it is "a theory that accounts for much of the behavior" (Glaser \& Strauss, 1967, p. 30) of the participants by generating general categories and their properties, to serve as a guide for others. Grounded theory results "are not proven; they are theory" (Glaser, 1992, p. 87). In accordance with this method, the researchers began by identifying an area of interest: the process of course design, as completed by university instructors.

\section{Data Source}

Fourteen college and university instructors (five males and nine females) from public fouryear institutions volunteered to take part in this study. Institutions ranged in size from 4,400 to 38,000 undergraduates. The instructors were from both teaching $(57 \%)$ and research $(43 \%)$ institutions located in urban environments. All but three of the participants held tenure-track or tenured positions. The participants' experiences ranged from having designed only one online 
course to having designed more than 50 online courses. Similarly, their experience teaching online varied between one and 19 years $(M=9.21)$ and included a variety of subjects (e.g., education, instructional design, statistics, English). All participants described themselves as having advanced technology skills, and all held terminal degrees in their fields. Using purposive sampling, the participants were chosen because they had different backgrounds but shared the experience of creating and teaching online courses.

\section{Procedure}

Instructors who had designed online courses were interviewed using open-ended interviews. Each participant was interviewed once, and the interviews were performed over the telephone. An application on the interviewer's cellular phone recorded the interviews. Before each interview began, the participant was told the purpose of the study and asked for his or her informed consent. Basic demographic information was acquired, and the participant's concerns and questions were discussed. Next, participants were asked the broad question, "Tell me about the process of how you design an online course.... Where do you begin?" with the intention to "instill the spill" (Glaser, 2009, p. 22). By following Glaser's (1999) guidelines of using an open question and prompting for more detail, participants were encouraged to keep talking about their main concerns within the area of interest (i.e., online course design). Additional questions were asked to understand the participants' perspective better, including the following:

- Where do you begin when designing online courses?

- How do you decide what to add?

- What training have you had to designing online courses?

- What supports are provided by your institution for online course design?

- Do you take advantage of these supports? Why or why not?

- Do you use a course evaluation rubric?

- What are the best and worst parts about designing an online course?

\section{Stages of Analysis}

To highlight information that appeared particularly significant, we took notes during each interview. Immediately after each interview, we transcribed the data. After reading through the transcripts several times, we coded the data by making notes of common categories and highlighting ideas of interest. Constant comparative analysis was used to compare data to find commonalities and variations (Creswell, 2007).

After the initial interviews, categories began to emerge. Morse (2008) describes categories as a collection of similar data brought together into the same place. In keeping with grounded theory procedures, we adjusted our interview questions. For example, the best and worst aspects of online course design were frequently mentioned by early participants, so these questions were incorporated into the interview procedure.

As patterns emerged, categories were distilled into general themes. Themes are a higher level of categorization that distill the concept further and have been described as "the meaningful 'essence' that runs through the data" (Morse, 2008, p. 727). For instance, one theme that surfaced in our study was refining the course based on student feedback. We made a list of themes and added pertinent points from each transcript. After the data had been taken apart through the coding analysis, these themes were used to piece the story together to develop a theory (Glaser, 1992). To 
determine whether the proposed theory held true for other participants, discriminant sampling (gathering additional information from new individuals) was used (Creswell, 2013) by interviewing additional participants (these instructors are included in the 14 individuals discussed earlier).

When (a) no new data emerged from the category, (b) the categories were dense enough to cover variations, and (c) relationships between categories had been delineated appropriately (Brown, Stevenson, Troiano, \& Schneider, 2002), theoretical saturation was determined to have been reached.

\section{Results}

The following themes emerged from the analysis:

- Instructors are assigned the task of course design and begin with objectives and/or existing course information, often utilizing information from face-to-face courses.

- Instructors build a structure, chunking content.

- Instructors rarely use formal instructional design models and rubrics.

- The learning management system (LMS) often reduces instructor freedom in online course design.

- Feedback from students is a major motivator for online course design after initial course delivery.

A central phenomenon in the design of online courses emerged as the data were examined: Online instructors do not follow formal instructional design processes. In fact, many of the participants were not aware that instructional design models even existed. The instructors designed online courses based on their experience with face-to-face courses and in accordance with the limitations of the LMS. Figure 1 shows the course design process that constitutes a theory "grounded" in the participants' reports. We have named this process and theory "informal design." The information provided by participants was conceptualized into a process model, using the themes that were developed from the coding of data into categories. 


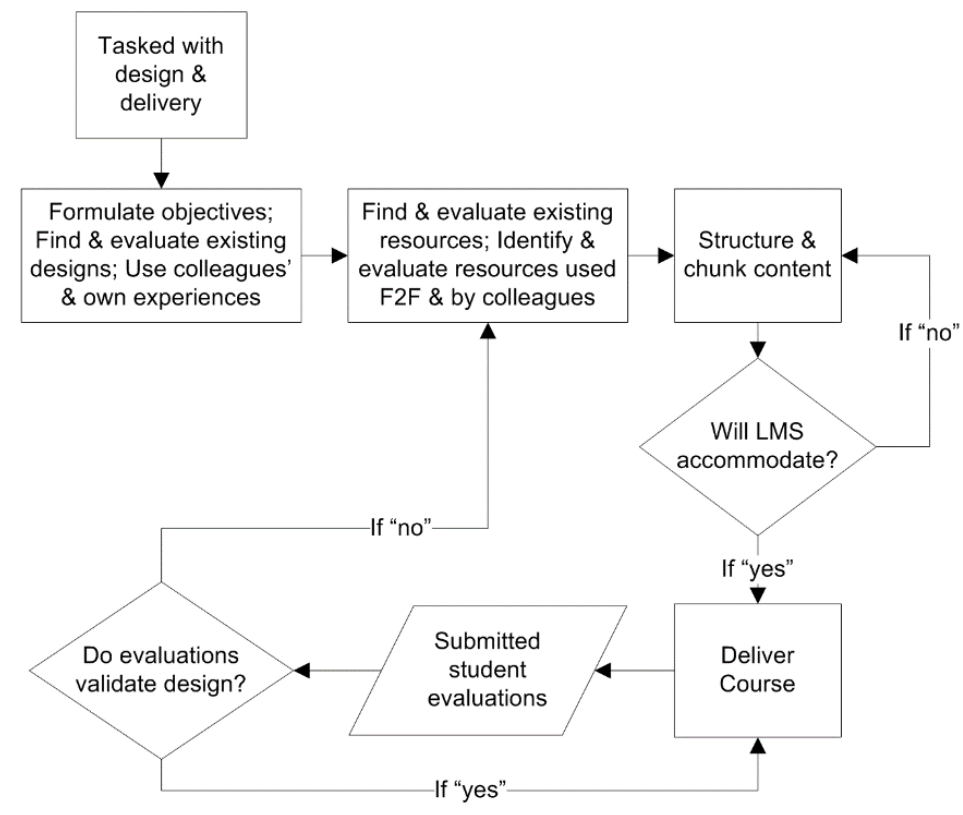

Figure 1. The informal design theory: A process model of instructors creating online courses.

For the participants, the entry point "tasked with design and delivery" represents the first stage of course design. Most of the participants learned how to design online courses by being the most technologically adept person in their department. This ability or interest designated them as the "go-to person" to design online courses. The participants described first looking at existing courses (e.g., face-to-face courses that they or someone else has developed). The participants look at course syllabi, which typically include course objectives, and work to understand the end result. If a face-to-face course does not exist at their institution, the participants report searching online for syllabi to help guide their course development. A common sentiment was, "I start by seeing what other people have already done." This information helps guide the participants, particularly in the early stages.

The participants consider the objectives for the course. A participant explained that he thinks about how to "translate those goals and objectives into online learning activities and formative assessments that can be carried out in the online environment." One participant stated,

I look at the objectives of the course. I obviously look at the course title and, I kind of think, okay, what key things regarding this specific topic do we want our students to be prepared with, and what objectives and standards do I need to interject to make everything align?

The next step the participants described was to find and evaluate existing resources. A participant suggested, "I look online to see if there are ... other resources that are out there." Gathering resources can be time consuming, but the participants indicated that this process helps provide students with current information and avoids the even more time-consuming task of building materials from scratch. Past teaching experience informs course design. Many of the participants mentioned "finding ways to take what was being done in the classroom and replicating 
those things online" or figuring out how to make an assignment work online, since the media and affordances are quite different. As one participant acknowledged, "Not all content or activities that work well in a face-to-face environment are going to translate online, but at least getting the sense of what has been done in the past I think is always helpful." Another participant described how he uses online reflective journals and VoiceThread peer reviews to "find ways to take what was being done in the classroom and replicate those things online."

Once resources have been collected, the participants structure and chunk content. The participants consider the length of the semester, the number of students, and available resources (e.g., technology, students' comprehension level, and existing knowledge). The instructors keep students engaged by distributing assignments and activities throughout the semester. Tasks are evenly paced to avoid overwhelming the students or the instructor. One participant noted, "I take the topics and ... plot out the various chunks of the course, so its organized by weeks or modules, then I try to break out each of those pieces." The participants often put the content into a set format. For example, one participant stated, "Each week I try to have the same order...there is always an overview, with the objectives, assignments due, and what is coming up in the future to try to keep [students] up to date."

The participants upload the course content to their institutions' LMS as the next step in the online course design process. The participants are often frustrated by this step, regardless of the brand of LMS (e.g., Blackboard, Canvas, Moodle). The LMSs were not deemed difficult to use, but they were described as "unresponsive," "unwiedly," and "time-consuming." And these were evaluations reported by participants who had earlier self-identified as "technologically savvy." A participant stated, "There are things I want to do that I can't do, I get frustrated by the limitations of [LMS]." Another participant stated, "The LMS constrains what you are able to do." Other participants mentioned redundant features within the software: "I tried to be responsive for students wanting more time, so I changed the due date in one place, but I didn't realize that I had to change it in another place." The participants saw the LMS as a component that demands time and energy and represents a hurdle in the course design process.

Once an online course has been deployed, the participants are eager for student feedback. The participants liked

getting to the end of the course and reading in a student's evaluation that they never thought that they could be successful or that they would even like an online course, but, by golly, they liked mine, their attitude adjusted, and that's my victory.

Another participant felt validated by

the feedback I get from students when it is a well-designed course. When things are easy to find, students find that they are engaged and they get so much out it. To get the feedback from the students saying this was the best course they ever taken. That kind of feedback, that really makes it all worth it.

Feedback from students motivated participants and encouraged them to continue to improve their courses. Since the initial goal for many of the participants was to get the course up and running for students, course refinement was often mentioned by participants as a way to adjust the course design to student feedback. Student feedback was also seen as a way of improving the experience for themselves and students. A participant reported that student feedback about course navigation led her department to implement a template for all online courses. Now, according to the 
participant, students "know where to find things because it's always pretty much in the same spot in every class so they're not trying to find where the information is, which could lead to confusion." As a result of this change, the participant reported spending less time helping students find items within the course. She stated, "I think that the feedback from students really improved ... the consistency in our department across courses."

\section{Discussion}

Course design for our participants began with a need to take action to complete a task (i.e., develop an online course). While our participants did not follow a formal instructional design process or rely upon instructional design models per se, they seem to have followed a process that mirrors the ADDIE model to a surprising degree (Figure 2). Similar to the ADDIE model, objectives were established, and the learning environment was analyzed, but our participants did not mention identifying learners' existing knowledge and skills. It is possible that analyzing learners' needs was less significant to our participants since most already had experience with teaching similar content and presumably similar students face-to-face. Next, our participants created content, and selected media, often based on existing resources (the design and development phases of ADDIE). And then the instruction was implemented, evaluated, and revised (the last two phases of ADDIE). Generally, the steps our participants outlined involved creating a solution for a complex task more than undertaking a systematic series of predefined actions or processes.

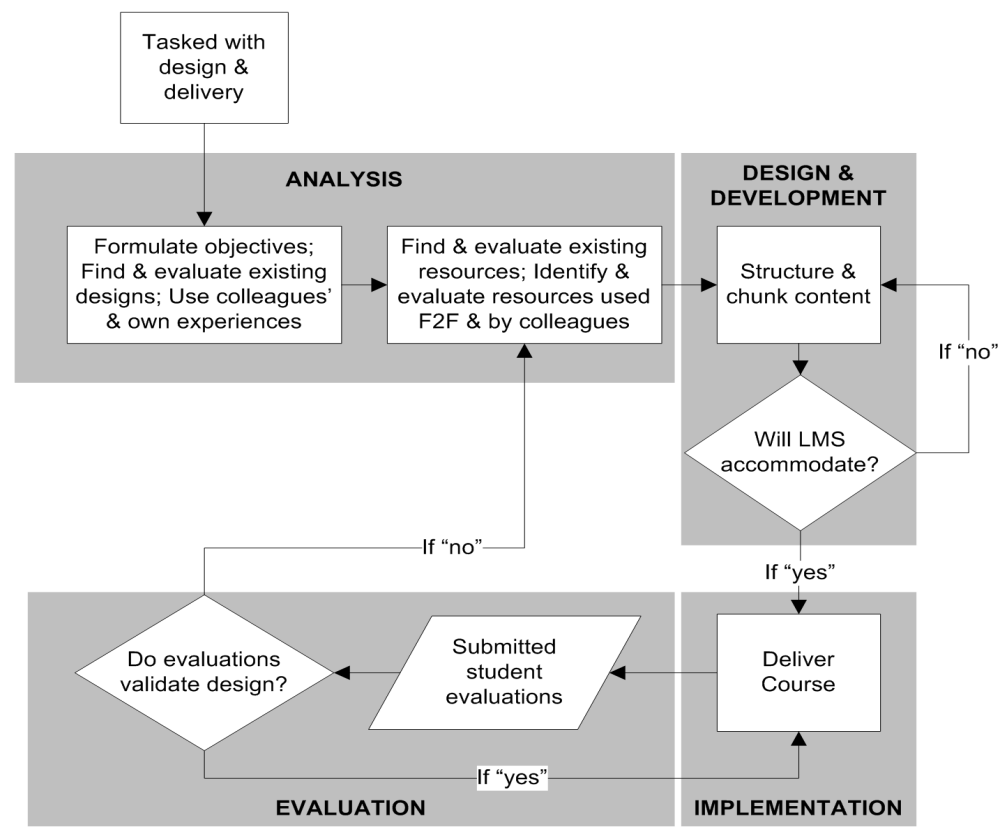

Figure 2. The informal design theory process model with steps in the ADDIE model superimposed.

The informal design theory represents a dynamic problem-solving approach to the online course design process. Research demonstrates that design is often solution driven (Rothwell \& Kazanas, 2011; Visscher-Voerman \& Gustafson, 2004), as seen by the participants in this study. 
As mentioned, many of the participants start with objectives, often obtained from face-to-face courses. However, to ensure students meet these objectives in an online course, the participants must develop new curriculum with instructional strategies effective for online learning. Online instructors must deliver content in a way that attracts, engages, and educates students in this environment (Rovai, 2004). Effective online courses utilize a range of instructional activities designed to engage the learner (Dempsey \& Van Eck, 2012). To this end, an updated definition of instructional design has been suggested as "the conscious generation of interventions into the experience of others for specific purposes" (Bichelmeyer, Boling, \& Gibbons, 2006, p. 39). This explanation aligns with our study's findings.

\section{Scholarly Significance of the Study}

The findings of this study provide a better understanding of how instructors design online courses and the factors that influence their actions. The participants approached online course design as a problem to be solved directly, on its own terms, based on whatever informal resources were immediately available. The participants did not see course design as a specialized undertaking, requiring expert personnel or highly specialized resources (e.g., research articles or guidebooks). At the same time, they reported following steps that generally correspond to those in the ADDIE process model, at least in its broadest outlines, in a pattern of actions that apparently arose almost spontaneously.

This presents a significant paradox for instructional design: Many are doing it—at least in rudimentary ways - but without knowing or explicitly following its established models and prescriptions. Systematic design processes and design models have been developed through scientific research, but these processes are not used as such, as our study shows. In this study, even participants who are instructors of instructional design do not explicitly follow the very models and processes they teach and espouse. Other studies (e.g., Gray et al., 2015; York \& Ertmer, 2011) indicate that this disconnect also applies to instructional design professionals in their own course design processes. Perhaps these models are not well suited for use in the everyday context of online course design at colleges and universities. The roots of instructional design are in training and developing materials for the military and industry, not for online education per se. It may also be the case that instructional design models are not readily accessible to instructors. In cases where they are available, it may be that the design models are presented in a manner that is difficult to use or in a way that fails to address the instructors' immediate concerns. Or, the time commitment required to follow systematic design processes and design models may be too much. Future research could investigate why these processes and models are not widely referenced. Future research could also provide more information on why instructors' use this process when designing online courses.

The findings of this study help to shed light on the design process used in a wide range of courses developed under similar conditions. In so doing, it also provides a basis for generating hypotheses for future research. Future research could investigate whether introducing the informal design theory could better prepare instructors who are new to online course design to course design tasks. This information could then be disseminated to instructors who are creating online courses to encourage greater quality and, correspondingly, more confidence in online courses.

\section{Practical Implications}

There are practical implications for colleges and universities interested in improving the quality of online courses. By understanding how instructors design online course (e.g., the informal 
design theory), institutions may be able to provide professional development activities to reinforce solution-driven design. Professional development could be developed to help instructors create effective objectives for their courses, learn how to better analyze the learning environment and their learners, provide resources to create content, and learn how to select appropriate media for online courses, as well as best practices when using learning management systems. The ADDIE process could be presented (or in some cases reintroduced) to help support instructors who design online courses.

Understanding the process instructors use when designing online courses provides insight into the steps instructors take to bring content to students. Stakeholders interested in improving online course quality may consider providing more resources for instructors at the key points mentioned (e.g., when faculty are reviewing existing designs). This could be done by sharing exemplary courses or providing fellow instructors with feedback on effective elements and content in their online courses. Also, institutions or LMS organizations may consider offering templates to help structure and chunk content.

\section{Limitations}

As with all research, there are limitations to this study. The use of grounded theory as a research method relies upon the researchers' ability to be sensitive to drawing concepts from the data. We attempted to increase the plausibility of the theory by fitting (almost) all of the evidence or concepts provided in the data into the theoretical account to show the participants' viewpoints. The theory fits the current set of participants based on the data collected. This study may be limited in its fit and modifiability should new or different data be collected. However, we attempted to limit these issues by performing constant comparison of data throughout the data collection and analysis process and by reaching theoretical saturation with the data collection.

Furthermore, this study was based on interviews with instructors whose views may or may not represent the views of a larger group. The transferability may be questioned since the instructors who volunteered to participate may represent a sample that views online education, course design, and instruction in particular ways. They also represent a group that designs courses without the assistance of instructional designers.

Finally, the use of grounded theory as a research method relies upon the creativity of the researcher and his or her ability to be sensitive to drawing concepts from the data. In working through the collection and coding process, we tried to focus on the tenets of grounded theory, based on our understanding. Grounded theory is subjective, and our personal bias formed a part of the study. The researchers' backgrounds include the roles of instructor, instructional designer, and online student. This knowledge and understanding helped generate categories (i.e., develop theoretical sensitivity), but the process of constant comparison encouraged us to look at the emerging phenomenon from many directions. These aspects should be considered for researchers wishing to verify the research. 


\section{References}

Allen, I. A., \& Seaman, J. (2016). Online report card. Tracking online education in the United States. Babson Park, MA: Babson Survey Research Group.

Alvarez, I., Guasch, T., \& Espasa, A. (2009). University teacher roles and competencies in online learning environments: A theoretical analysis of teaching and learning practices. European Journal of Teacher Education, 32(3), 321-336.

Baran, E., Correia, A.-P., \& Thompson, A. (2011). Transforming online teaching practice: Critical analysis of the literature on the roles and competencies of online teachers. Distance Education, 32(3), 421-439. doi:10.1080/01587919.2011.610293

Barberà, E., Layne, L., \& Gunawardena, C. N. (2014). Designing online interaction to address disciplinary competencies: A cross-country comparison of faculty perspectives. The International Review of Research in Open and Distributed Learning, 15(2). Retrieved from http://www.irrodl.org/index.php/irrodl/article/view/1418/2840

Bawane, J., \& Spector, J. M. (2009). Prioritization of online instructor roles: Implications for competency-based teacher education programs. Distance Education, 30(3), 383-397. doi:10.1080/01587910903236536

Becker, K. (2007). Wicked ID: Conceptual framework for considering instructional design as a wicked problem. Canadian Journal of Learning and Technology/La revue Canadienne de L'apprentissage et de la Technologie, 33(1). Retrieved from https://ejournals.library.ualberta.ca/index.php/cjlt/article/view/26459/19641

Bichelmeyer, B., Boling, E., \& Gibbons, A. S. (2006). Instructional design and technology models: Their impact on research and teaching in instructional design and technology. In M. Orey, V. J. McClendon, \& R. M. Branch (Eds.), Educational media and technology yearbook (Vol. 31, pp. 33-73). Littleton, CO: Libraries Unlimited, Inc.

Boling, E., \& Smith, K. M. (2012). The changing nature of design. In R. A. Reiser \& J. V. Dempsey (Eds.), Trends and issues in instructional design and technology (3rd ed., pp. 358-366). Saddle River, NJ: Pearson Education.

Branch, R. M., \& Merrill, M. D. (2012). Characteristics of instructional design models. In R. A. Reiser \& J. V. Dempsey (Eds.), Trends and issues in instructional design and technology (3rd ed., pp. 8-16). Saddle River, NJ: Pearson Education.

Brown, S. C., Stevenson, R. A., Troiano, P. F., \& Schneider, M. K. (2002). Exploring complex phenomena: Grounded theory in student affairs research. Journal of College Student Development, 43(2), 173-183.

Christensen, T. K., \& Osguthorpe, R. T. (2004). How do instructional-design practitioners make instructional-strategy decisions? Performance Improvement Quarterly, 17(3), 45-65.

Clark, D. R. (2015). ADDIE timeline. Retrieved from http://www.nwlink.com/ donclark/history isd/addie.html

Creswell, J. W. (2007). Educational research: Planning, conducting, and evaluating quantitative and qualitative research (4th ed.). Upper Saddle River, NJ: Pearson. 
Creswell, J. W. (2013). Qualitative inquiry and research design: Choosing among five approaches (3rd ed.). Thousand Oaks, CA: Sage.

Dempsey, J. V., \& Van Eck, R. N. (2012). E-learning and instructional design. In R. A. Reiser \& J. V. Dempsey (Eds.), Trends and issues in instructional design and technology (3rd ed., pp. 281-289). Saddle River, NJ: Pearson Education.

Dick, W., Carey, L., \& Carey, J. O. (2014). The systematic design of instruction (8th ed.). San Francisco, CA: Pearson Education.

Ertmer, P. A., Stepich, D. A., York, C. S., Stickman, A., Wu, X. L., Zurek, S., \& Goktas, Y. (2008). How instructional design experts use knowledge and experience to solve illstructured problems. Performance Improvement Quarterly, 21(1), 17-42.

Fink, L. D. (2003). A self-directed guide to designing courses for significant learning. Retrieved from http://www.deefinkandassociates.com/GuidetoCourseDesignAug05.pdf

Glaser, B. G. (1978). Theoretical sensitivity: Advances in the methodology of grounded theory. Mill Valley, CA: Sociology Press.

Glaser, B. (1992). Basics of grounded theory analysis: Emergence vs. forcing. Mill Valley, CA: Sociology Press.

Glaser, B. G. (2009). Jargonizing: Using the grounded theory vocabulary. Mill Valley, CA: Sociology Press.

Glaser, B., \& Strauss, A. (1967). The discovery of grounded theory: Strategies for qualitative research. Hawthorne, NY: Walter de Gruyter, Inc.

Gray, C. M., Dagli, C., Demiral-Uzan, M., Ergulec, F., Tan, V., Altuwaijri, A. A., ... Boling, E. (2015). Judgment and instructional design: How ID practitioners work in practice. Performance Improvement Quarterly, 28(3), 25-49.

Huguet, M. C. (2008). Rethinking instructional design: Considering the instructor-A case study [Doctoral dissertation]. Retrieved from ProQuest Dissertations \& Theses Global. (304352638)

Ippoliti, C. M., \& Gammons, R. W. (2016). User-centered design for first-year library instruction programs. Denver, CO: Libraries Unlimited.

Jaschik, S., \& Lederman, D. (Eds.). (2014). Faculty attitudes on technology. Inside Higher Ed, $1-44$.

Kang, S. (2000). An investigation of instructional design processes for web-based courses. [Doctoral dissertation]. Retrieved from ProQuest Dissertations \& Theses Global. (304613134)

Keller, J. M. (1987). Development and use of the ARCS model of instructional design. Journal of Instructional Development, 10(3), 2-10.

Kenny, R., Zhang, Z., Schwier, R., \& Campbell, K. (2005). A review of what instructional designers do: Questions answered and questions not asked. Canadian Journal of Learning and Technology/La revue Canadienne de L'apprentissage et de la Technologie, 31(1). Retrieved from http://cjlt.csj.ualberta.ca/index.php/cjlt/article/view/147/140 
Kihato, M., \& Bednar, C. (2004). Importance of online course components: A survey of instructors and students. Journal of the American Dietetic Association, 104(40), 9-26.

Kirschner, P., Carr, C., van Merriënboer, J., \& Sloep, P. (2002). How expert designers design. Performance Improvement Quarterly, 15(4), 86-104.

Koszalka, T. A., \& Ganesan, R. (2004). Designing online courses: A taxonomy to guide strategic use of features available in course management systems (CMS) in distance education. Distance Education, 25(2), 243-256.

McDonald, J. (2009). Designing and implementing online discussion forums: An Australian case study. International Journal of Networking and Virtual Organisations, 6(5), 518-531.

Merrill, M. D., Drake, L., Lacy, M. J., \& Pratt, J. (1996). Reclaiming instructional design. Educational Technology, 36(5), 5-7. Retrieved from http://mdavidmerrill.com/Papers/Reclaiming.PDF

Miller, J. L. (2007). The new education professionals: The emerging specialties of instructional designer and learning manager. International Journal of Public Administration, 30(5), 483-498. doi:10.1080/01900690701205970

Morrison, G. R., Ross, S. M., Kemp, J. E., \& Kalman, H. (2010). Designing effective instruction. New York, NY: John Wiley \& Sons.

Morse, J. M. (2008). Confusing categories and themes. Qualitative Health Research, 18(6), $727-$ 728.

Reigeluth, C. M. (Ed.). (2013). Instructional design theories and models: An overview of their current status. Hillsdale, NJ: Lawrence Erlbaum Associates, Publishers. Retrieved from http://bit.ly/2iZXnho

Rothwell, W. J., \& Kazanas, H. C. (2011). Mastering the instructional design process: A systematic approach. New York, NY: John Wiley \& Sons.

Rovai, A. P. (2004). A constructivist approach to online college learning. The Internet and Higher Education, 7(2), 79-93.

Seaman, J. (2009). Online learning as a strategic asset. Volume II: The paradox of faculty voices-views and experiences with online learning. Results of a national faculty survey, part of the online education benchmarking study. Conducted by the APLU-Sloan National Commission on Online Learning. Association of Public and Land-grant Universities.

Silber, K. H. (2007). A principle-based model of instructional design: A new way of thinking about and teaching ID. Educational Technology, 47(5), 5-19.

Smith, P. L., \& Ragan, T. J. (2004). Instructional design (3rd ed.). New York, NY: Wiley.

Straumsheim, C., Jaschik, S., \& Lederman, D. (Eds.). (2015). 2015 Inside Higher Ed survey of faculty attitudes on technology. Inside Higher Ed, 1-49. Retrieved from http://bit.ly/1KaWq9I

Swan, K. (2001). Virtual interaction: Design factors affecting student satisfaction and perceived learning in asynchronous online courses. Distance Education, 22(2), 306-31. 
Visscher-Voerman, I., \& Gustafson, K. L. (2004). Paradigms in the theory and practice of education and training design. Educational Technology Research and Development, 52(2), 69-89.

Wedman, J., \& Tessmer, M. (1993). Instructional designers' decisions and priorities: A survey of design practice. Performance Improvement Quarterly, 6(2), 43-57.

West, J. A., \& West, M. L. (2009). Using wikis for online collaboration: The power of the readwrite web. Hoboken, NJ: John Wiley \& Sons.

Wiggins, G., \& McTighe, J. (1998). Understanding by design. Alexandria, VA: ASCD.

Worthen, H. (2013). What do we know about teaching online? Academe, 99(5), 28-33.

York, C. S., \& Ertmer, P. A. (2011). Towards an understanding of instructional design heuristics: An exploratory Delphi study. Educational Technology Research and Development, 59(6), 841-863.

Zierer, K., \& Seel, N. M. (2012). General didactics and instructional design: Eyes like twins. A transatlantic dialogue about similarities and differences, about the past and the future of two sciences of learning and teaching. SpringerPlus, 1(1), 1-22. 
Online Course Design and Development Among College and University Instructors: An Analysis Using Grounded Theory 